\title{
PENGUATAN KAPASITAS PERAN MASJID SEBAGAI PUSAT PEMBERDAYAAN MASYARAKAT DI KELURAHAN TAMAN SARI AMPENAN KOTA MATARAM
}

\author{
Akhmad Asyari ${ }^{1}$, Subhan Abdullah Acim ${ }^{2}$ \\ ${ }^{1}$ Dosen Tetap Fakultas Tarbiyah dan Keguruan IAIN Mataram \\ ${ }^{2}$ Dosen Tetap Fakultas Dakwah dan Komunikasi Islam IAIN Mataram
}

\begin{abstract}
Abstrak: Berdasarkan hasil observasi awal yang telah dilakukan ditemukan permasalahan yang urgen untuk ditindak lanjuti yaitu rendahnya pemahaman keagaamaan masyarakat dan rentannya pengaruh budaya disebabkan masyarakat yang menetap dan tinggal di kelurahan taman sari Ampenan ini sangat heterogen dari suku, kepercayaan dan latar belakang. Untuk mencegah dampak negatif yang terjadi maka masjid harus difungsikan sebagai sarana dan fungsi/peran kapasitas masjid tidak hanya sebagai tempat melaksanakan ibadah, tetapi masjid harus dijadikan sebagai pusat pemberdayaan masyarakat. Kegiatan pendidikan dan penyuluhan dilaksanakan pada hari jum'at-sabtu tanggal 05-06 Agustus 2017 yang bertempat di masjid Al Falah dengan jumlah peserta sejumlah 30 orang dan terdiri dari 2 orang Narasumber yaitu bapak Dr. H. Zaidi Abdad, MA yang merupakan dosen UIN Mataram pada jurusan Ekonomi Islam dan bapak M. Sa'i, MA yang juga akademisi yaitu dosen fakultas Dakwah IAIN Mataram. Adapun kesimpulan dari kegiatan ini adalah; (1) Kegiatan pengabdian dapat terlaksana dengan lancar yang tercermin dari maksimalnya peran dari setiap tim pelaksana kegiatan pengabdian. (2) Berubahnya pola pikir masyarakat terhadap pentingnya pemberdayaan masjid. (3) Meningkatnya pemahaman keagamaan masyarakat yang lebih moderat dalam melihat masjid bukan sekedar sebagai tempat melaksanakan ibadah, tetapi masjid justru berperan sebagai pusat pemberdayaan masyarakat. (4) Meningkatnya pemahaman masyarakat terkait dengan konsep kapasitas peran masjid sebagai pusat pemberdayaan. (5) Tersampaikannya informasi terkait dengan penguatan kapasitas peran masjid sebagai pusat pemberdayaan. (6) Meningkatnya pemahaman masyarakat untuk menjadikan masjid sebagai pusat pemberdayaan masyarakat.
\end{abstract}

Kata Kunci: Kapasitas Peran Masjid, Pusat Pemberdayaan Masyarakat, Tamansari Ampenan Kota Mataram.

\section{PENDAHULUAN}

Perkembangan umat Islam pada periode awal tidak lepas dari masjid. Masjid adalah suatu tempat (bangunan) yang fungsi utamanya sebagai tempat melaksanakan ibadah shalat bersujud untuk menyembah Allah SWT. Firman Allah SWT dalam surat al-Jin ayat 18: "Dan sesungguhnya masjid-masjid itu adalah kepunyaan Allah. Maka janganlah kamu menyembah seseorang pun di dalamnya di samping (menyembah) Allah." 
Di samping sebagai tempat beribadah umat Islam dalam arti khusus (mahdhah), masjid juga merupakan tempat beribadah secara luas (ghairu mahdhah) selama dilakukan dalam batas-batas syari'ah. Masjid yang besar, indah dan bersih adalah dambaan kita, namun semua itu belum cukup apabila tidak ditunjang dengan kegiatan-kegiatan memakmurkan masjid. Masjid menjadi pilar spiritual yang menyangga kehidupan duniawi umat.

Masjid mencerminkan seluruh aktivitas umat, masjid menjadi pengukur dan indikator dari kesejahteraan umat baik lahir maupun batin. Oleh sebab itu, jika tidak ada masjid diwilayah yang berpenduduk agama Islam atau ada masjid di tengah penduduk Islam, tetapi tidak digunakan sebagai pusat kehidupan umat, ini akan menjadi isyarat negatif timbulnya dis-orientasi kehidupan umat. Dalam dua situasi ini, umat akan mengalami kebingungan dan menderita berbagai penyakit mental maupun fisik serta tidak dapat menikmati distribusi aliran ridha dan energi dari Allah SWT.

Masjid sebagai pranata sosial Islam sekaligus media rahmatan lil alamin hanya bisa terwujud jika masjid menjalankan peran dan fungsinya. Namun, seringkali peran masjid tidak berjalan baik karena pengelolaannya yang kurang tepat. Untuk itu, fungsi dan peran masjid sebagai lembaga sosial sesuai dengan tuntunan ajaran agama dalam dimensi kekinian harus di revitalisasikan kapasitas peran dan fungsinya.

Fenomena masjid yang terjadi saat ini, fungsi dan peranannya tidak lagi terarah sesuai dengan harapan. Masjid tetap sebagai tempat penyelenggaraan ibadah, artinya berfungsi sebagai pusat pembinaan mental spiritual, akan tetapi penyelenggaraan ibadah semakin menyempit. ${ }^{1}$ Padahal, masjid memiliki peran strategis sebagai pusat pembinaan dalam upaya

${ }^{1}$ Robiatul Auliyah, Studi Fenomenolgi peranan manajemen masjid at-Taqwa dalam pemberdayaan ekonomi masyarakat Bangkalan, (Madura:Universitas Trinujoyo Madura, 1986), h.204. 
Transformasi, Vol. 13, No. 1, Januari 2017: 14 - 26

melindungi, memberdayakan, dan mempersatukan umat untuk mewujudkan umat yang berkualitas, moderat dan toleran. Masjid kita, hampir tidak memiliki kepedulian needs jama'ahnya. Hal ini diperkuat dengan observasi dan wawancara awal yang dilakukan oleh pengabdi, pada masjid al-Falah dan beberapa masjid yang ada di Kelurahan Taman sari Ampenan Kota Mataram.

Ketika harus melihat eksistensi masjid di era sekarang dalam pengertian fisik, masjid masih memiliki pengertian yang sangat sempit, hanya sebagai tempat aktifitas shalat yang ritmenya masih kalah jauh dibanding ruang publik lain yang bersifat umum, oleh karena itu masjid masih harus bersaing dengan gedung- gedung mewah pencakar langit yang menjadi pusat hiburan dan juga harus berhadapan dengan pabrik-pabrik berskala raksasa, tempat kesayangan para pencari rezeki. Selain itu, pembangunan masjid yang semakin marak tidak diikuti oleh mutu pemberdayaan, sehingga masjid terkesan tidak dapat memberikan manfaat sosial bagi masyarakat.

Sejauh ini, ada juga beberapa masjid yang menjalankan peran ibadah, pendidikan, dan ekonomi masjid, walaupun peran dan fungsi yang digarap belum maksimal dijalankan. Peran ekonomi dijalankan dengan tujuan agar bisa menjadi masjid yang mandiri, artinya masjid tidak hanya bergantung pada dana jama'ah. Berangkat dari konsep normativitas akan masjid dan historisitas faktual yang dilaksanakan Nabi Muhammad SAW pada masa hidupnya, menunjukkan bahwa apa yang dilakukan Nabi Muhammad SAW terhadap masjid, ternyata tidak sebatas pada pemaknaan sajada yang formal dan sederhana sebagaimana yang lazim dipahami dan diapresiasi oleh masyarakat muslim saat ini, yakni sebagai tempat shalat dan melaksanakan aktivitasaktivitas rutin untuk menumbuhkembangkan keshalehan individual. Tetapi lebih dari itu, masjid dijadikan oleh Nabi Muhammad SAW sebagai lembaga 
Akhmad Asyari, Subhan Abdullah Acim, Penguatan Kapasitas...

penumbuhkembangan keshalehan sosial dalam rangka menciptakan masyarakat religion-politik menurut tuntunan ajaran Islam. Pada masa itu, masjid sepenuhnya berperan sebagai lembaga rekayasa sosial yang sesuai dengan tuntunan ajaran agama Islam.

Untuk mencapai hasil yang optimal perlu didukung dengan sistem, aktivitas dan lembaga pemberdayaan masjid. Gerakan ini diharapkan dapat berlangsung secara massal dan melibatkan banyak komponen umat, baik Pengurus Masjid, Ulama, Umara, Ustadz, Mubaligh, Intelektual, Aktivis organisasi Islam, Pemerintah, Politisi muslim maupun kaum muslimin pada umumnya. Masjid menjadi pangkal tempat Muslim bertolak, sekaligus pelabuhan tempatnya berlabuh.

\section{PEMBAHASAN}

\section{Model Pengembangan Ekonomi melalui Masjid}

Melihat apa yang dilakukan Rasulullah yakni dengan mengeluarkan kebijakan pembangunan masjid sebagai sentra kegiatan Islam dalam segala aspek baik muamalah, siasah, dll merupakan salah satu bentuk atau model pembangunan ekonomi yang dicontohkan oleh Rasulullah saat itu. Ini menjadi salah satu hal yang menarik untuk dibahas dimana masjid digunakan sebagai sentral kegiatan muamalah.

Pada dasarnya penggunaan masjid sebagai dasar pembangunan sistem ekonomi yang berbasis keislaman merupakan suatu hal yang sangat tepat untuk dilakukan. Pada zaman Rasulullah masjid juga digunakan sebagai sarana pembelajaran untuk mendalami ilmu-ilmu keislaman dan menguatkan ukhuwah dan jamiah Islamiah diantara kaum muhajirin dan anshar pada saat itu. Jika dikorelasikan antara peranan masjid dan pengembangan ekonomi Islam, maka masjid akan digunakan sebagai penguat pondasi-pondasi keislaman dan pembelajaran tentang teori-teori muamalah sebelum diterapkan didunia riil. Masjid mempunyai fungsi yang vital dalam pembentukan karakter ekonomi yang rabbani sehingga sistem ekonomi yang Islami tersebut bisa dijalankan secara sempurna. 
Di bidang ekonomi, masjid pada awal perkembangan Islam di gunakan sebagai "Baitul Mal" yang mendistribusikan harta zakat, sedekah, dan rampasan perang kepada fakir miskin dan kepentingan Islam. ${ }^{2}$ Golongan lemah pada waktu itu sangat terbantu dengan adanya baitul mal.

Masjid berarti tempat untuk bersujud. Secara terminologis diartikan sebagai tempat beribadah umat Islam, khususnya dalam menegakkan salat. Masjid sering disebut baitullah (rumah Allah), yaitu bangunan yang didirikan sebagai sarana mengabdi kepada Allah. Sedangkan teknologi secara harfiah berarti keseluruhan sarana untuk menyediakan barang-barang yang diperlukan bagi kelangsungan dan kenyamanan hidup manusia. Masjid dan teknologi merupakan dua hal yang berkaitan, masjid sebagai tempat ibadah, dan teknologi merupakan penunjang dari peribadatan itu sendiri. Kemajuan teknologi yang berkembang pesat tidak dapat dibendung, perubahanperubahan dan penemuan-penemuan yang terus terjadi memberikan dampak yang cukup besar bagi peradaban manusia.

Contoh sederhana misalnya pengeras suara, dengan teknologi pengeras suara, suara azan yang dikumandangkan di masjid akan terdengar ke seantero kampung. Teknologi yang nyata yang memiliki dampak baik bagi perkembangan yang ada. Pernah dengar Masjid Salman Institut Teknologi Bandung (ITB)? Masjid Salman ITB merupakan salah satu masjid yang tidak memiliki kolom (tiang) di tengah bangunan. Kenapa tidak berkolom? Apakah masjidnya kuat? Pertanyaan seperti itu muncul. Namun dengan perkembangan teknologi dan material bangunan, kita bisa membuat masjid tanpa kolom. Adapun tujuan tanpa kolom tersebut tidak lain dan tidak bukan untuk kesempurnaan salat berjamaah. Adanya kolom membuat shaf menjadi putus, namun dengan teknologi hal tersebut dapat diatasi.

Selanjutnya Masjid Nabawi, yang merupakan salah satu masjid terpenting yang terletak di Kota Madinah, Arab Saudi, dibangun oleh Nabi Muhammad SAW dan menjadi makam Rasulullah dan para sahabat. Masjid ini

\footnotetext{
${ }^{2}$ Hamid Syarif, Abd, Peranan Masjid dalam pengembangan ekonomi Islam: Sebuah kebijakan ekonomi Zaman Rasulullah, 2000, h.32.
} 


\section{Akhmad Asyari, Subhan Abdullah Acim, Penguatan Kapasitas...}

merupakan salah satu masjid yang utama bagi umat muslim setelah Masjidil Haram di Makkah dan Masjidil Aqsa di Palestina. Kita selalu mendengar cerita dari sanak keluarga yang pergi haji dan umrah, bahwa Masjid Nabawi memiliki atap atau payung-payung modern antipanas dan kubah yang yang bisa menutup dan membuka dalam waktu beberapa detik. Total kubah tersebut berjumlah 27 buah dan berbobot 80 ton. Hal tersebut merupakan salah satu contoh penerapan teknologi pada bangunan masjid. Payung raksasa ini berfungsi sebagai peneduh panas, dapat terbuka dan tertutup secara otomatis sebagai pelindung bagi jamaah yang beribadah. Kubah-kubah masjid juga berfungsi sebagai pengatur udara dalam bangunan, kubah tersebut bisa dibuka dan ditutup secara elektronik dan manual.

Kenyamanan lain Masjid Nabawi adalah memiliki marmer super mahal yang mampu mengubah suhu panas menjadi dingin. Tidak heran jika pertama kali menginjakkan kaki saat memasuki areal masjid, kaki kita terasa lebih sejuk. Jangan dilihat kemahalan marmer tersebut, tapi lihatlah bagaimana teknologi berperan dalam upaya menunjang kegiatan yang ada. Suhu di Makkah dan Madinah yang pada musim panas bisa mencapai 50C, yang mana radiasi matahari tersebut akan berpindah ke dalam masjid, sehingga bangunan secara keseluruhan akan menjadi panas. Dengan penggunaan teknologi pendingin lantai, hal itu dapat teratasi.

Dapat kita lihat bagaimana penggunaan teknologi itu mendukung kegiatan manusia di dalamnya untuk beribadah. Teknologi dimanfaatkan untuk memberikan kenyamanan, kekhusukan dalam upaya mendekatkan diri kepada Yang Maha Kuasa. Pada masa sekarang teknologi sudah diterapkan hampir di setiap masjid yang ada. Masjid-masjid besar nan megah dengan penggunaan teknologi canggih di dalamnya. Ada masjid dengan kubah yang besar nan indah, dengan kubah berwarna emas, ada masjid dengan minaret- minaret yang tinggi. Namun ada juga masjid yang tidak punya kubah, hanya berbentuk persegi. Pada dasarnya hal tersebut tidak masalah, karena fungi utama masjid sebagai tempat ibadah, tidak melihat bentuk maupun tingkat kebesaran dan 
Transformasi, Vol. 13, No. 1, Januari 2017: 14 - 26

kemegahannya. Perlu kita sadari, secanggih apapun teknologi, sehebat apapun bangunan masjid, serta semegah apapun masjid tersebut, tetaplah masjid yang ramai jamaahlah yang lebih baik. Jadi dapat kita pahami, teknologi merupakan pendukung dari fungsi masjid itu sendiri.

\section{PELAKSANAAN KEGIATAN}

Adapun langkah-langkah pada pelaksanaan kegiatan pengabdian desa binaan model yang dilakukan adalah sebagai berikut:

\section{Observasi Awal}

Kegiatan observasi awal dilaksanakan pada tanggal 20-21 April 2017, dimana pada saat pelaksanaan observasi pengabdi bertemu dengan Berdasarkan keterangan dari salah seorang tokoh agama tokoh masyarakat di masjid Al-Falah yaitu Bapak Agus Mahmud, M.Ag yang menjelaskan terkait dengan keberadaan masjid dan masyarakat di Kelurahan Taman Sari Ampenan Kota Mataram, dan diperoleh data bahwa di kelurahan Taman sari ini merupakan kelurahan baru dari kecamatan Ampenan dengan jumlah kepala keluarga yang ada di Kelurahan Taman sari terdiri dari kurang lebih $860 \mathrm{KK}$.

Masyarakat atau penduduk di kelurahan Taman sari ini sebagian besar adalah masyarakat pendatang dari berbagai daerah di Nusa Tenggara Barat, bahkan masyarakat yang tinggal dan menetap banyak dari pulau Jawa dan Luar Jawa (Sumatera). Meski berbeda asal, budaya, ras bahkan agama (kepercayaan), masyarakat kelurahan Taman sari bisa hidup berdampingan dengan baik dan rukun. Akan tetapi masyarakat yang paling banyak adalah penduduk muslim, maka tidak heran di Kelurahan Taman sari ini berdiri beberapa masjid besar dan beberapa pondok dengan majlis taklim yang berjalan dengan baik.

Akan tetapi, tentu dalam kehidupan bermasyarakat, tentu tersapat sisi posisitf dan negative, selain dampak positif yang ditimbulkan terdapat juga dampak negatif yaitu dengan maraknya perkembangan global dan budaya yang beragam akan mempengaruhi budaya dan istiadat masyarakat setempat, 
terlebih lagi dengan makin pesatnya perkembangan budaya yang sangat berbeda seperti sikap individualistik, paham liberalisme, hedonisme, dan pergaulan bebas sehingga masyarakat khususnya pemuda pemudi yang ada di daerah tersebut sangat rentan dipengaruhi oleh budaya asing tersebut yang nantinya akan mempengaruhi kepribadian masyarakat sekitar dan dapat menjadi pemicu adanya perpecahan.

Selain itu, karakteristik penduduk gili air yang sangat beragam baik dari tingkat pendidikan, mata pencaharian, dan aliran agama yang beragam merupakan potensi terhadap munculnya konflik sehingga sangat perlu dilakukan pendampingan melalui kegiatan pengabdian masyarakat (Desa Binaan Model) melalui peningkatan pemahaman tentang peran dan fungsi masjid sebagai pusat pemberdayaan masyarakat. Karena dengan interaksi dan transaksi masyarakat yang sudah berlebihan, masjid menjadi salah satu jalan keluar sebagai penyejuk hati, tausiah, ceramah sekaligus sebagai sarana pemberdayaan masyarakat.

Tujuan dilakukannya observasi awal dilakukan untuk mendapatkan informasi terkait dengan kondisi masjid dan kelurahan yang akan menjadi target pelaksanaan kegiatan desa binaan yaitu mengobservasi kondisi dan potensi masjid yang dimiliki kelurahan Taman Sari yaitu terkait dengan keadaan masyarakat, sarana dan prasarana, kondisi Sumber daya alam (SDA) kelurahan, kondisi pemerintahan kelurahan, budaya masyarakat setempat, dan kondisi Sumber daya Manusia yang dimiliki sehingga dari kegiatan observasi awal ini pengabdi dapat memotret secara komprehensif terkait dengan kondisi dan potensi desa serta permasalahan yang terjadi di Kelurahan Taman Sari yang nantinya akan menjadi fokus pengabdi dalam melakukan kegiatan pengabdian (Desa Binaan). Informasi ini diperoleh melalui kegiatan wawancara dengan pihak Kelurahan, tokoh agama, tokoh masyarakat, tokoh pemuda, yang ada di Kelurahan Taman Sari Ampenan Kota Mataram.

\section{Pemetaan Potensi dan Masalah}

Untuk menindak lanjuti hasil observasi dan pemetaan potensi desa, pada tanggal 20-21 April 2017 dan juga dengan mensinkronisasi data yang 
Transformasi, Vol. 13, No. 1, Januari 2017: 14 - 26

diperoleh untuk mendata potensi kelurahan baik dari segi potensi sumber daya alam, sumber daya manusia, dan potensi-potensi lain yang dimiliki oleh kelurahan Taman Sari Ampenan Kota Mataram tersebut maka pada tanggal 22-23 Mei 2017 dilakukan pemetaan masalah yang paling urgen dan mendesak untuk diselesaikan.

Berdasarakan hasil observasi awal terkait dengan potensi dan permasalahan yang dihadapi, maka strategi selanjutnya adalah dengan melakukan pemetaan potensi dan permasalahan yang urgen untuk ditindak lanjuti. Berdasarkan hasil observasi awal yang telah dilakukan ditemukan permasalahan yang urgen untuk ditindak lanjuti yaitu Berdasarakan hasil observasi awal terkait dengan potensi dan permasalahan yang dihadapi di pengelola/pengurus masjid, maka strategi selanjutnya adalah dengan melakukan pemetaan potensi dan permasalahan yang urgen untuk ditindak lanjuti. Berdasarkan hasil observasi awal yang telah dilakukan ditemukan permasalahan yang urgen untuk ditindak lanjuti yaitu rendahnya pemahaman keagaamaan masyarakat dan rendahnya kemampuan secara ekonomis masyarakat yang nantinya bisa berakibat tidak baik oleh generasi muda, maka perlunya menjadikan masjid sebagai sarana dan fasilitas untuk memberdayaan masyarakat menjadi sangat urgen.

Alasan memilih Kelurahan Taman Sari sebagai daerah dampingan adalah:

a. Masih lemahnya pola pikir masyarakat terhadap pentingnya peran masjid sebagai sarana pemberdayaan masyarakat

b. Kelurahan Ampenan Kota Mataram merupakan masyarakat yang sebagaian besar penduduknya adalah pendatang dari berbagai daerah yang tentunya memiliki karakter yang beragam.

c. Kelurahan Taman Sari Ampenan merupakan bagian dari wilayah mataram dengan motto Mataram Religius dan Berbudaya.

d. Masih lemahnya pemahaman masyarakat terkait dengan konsep pemberdayaan masjid 
e. Minimnya informasi terkait dengan masjid sebagai pusat pemberdayaan masyarakat, masyarakat seringkali memaknai dan mnerjemahkan masjid hanya sebagai tempat melaksanakan ibadah.

f. Tingkat kesadaran dan kepedulian masyarakat terhadap pemanfaatan masjid sebagai pusat pemberdayaan.

\section{Melakukan Kegiatan FGD}

Kegiatan FGD dilakukan dengan melibatkan seluruh kompenen pengurus dan pengelola masjid di Kelurahan Taman Sari Ampenan Kota Mataram yang terkait dengan fokus pengabdian yaitu Penguatan kapasitas peran masjid sebagai pusat pemberdayaan masyarakat yaitu dengan melibatkan pihak kelurahan, pengelola/pengurus masjid, tokoh pemuda, tokoh agama dan masyarakat setempat yang bertujuan untuk mendiksusikan solusi terbaik dari berbagai permasalahan tentang masjid sebagai pusat pemberdayaan masyarakat yang nantinya melibatkan potensi yang dimiliki oleh kelurahan dan tokoh masyarakat sehingga pada pelaksanaannya pengabdi hanya berperan sebagai fasilitator dan masayarakat dan pengelola/pengurus yang menjadi pelaku utama dalam pelaksanaan program yang akan dilaksanakan.

\section{Tahap Persiapan Pelaksanaan Kegiatan Pengabdian}

Pada tahap ini hal yang dipersiapkan adalah Penentuan peserta pengabdian yang mewakili setiap pengurus masjid/pengelola masjid, tokoh agama, pemuda dan masyarakat yang ada di Kelurahan Taman Sari Ampenan Kota Mataram. Adapun narasumber yang akan memberikan materi yaitu akademisi yang ahli dan kompeten di bidangnya yaitu bapak $\mathrm{Dr}$. KH. Zaidi Abdad, MA yang merupakan tokoh masyarakat, tokoh agama, pimpinan pondok pesantren serta akademisi IAIN Mataram pada jurusan Ekonomi Islam Fakultas Syariah IAIN Mataram dan bapak M. Sa'i, MA yang juga akademisi yaitu dosen jurusan BKI pada fakultas Dakwah IAIN Mataram, beliau juga merupakan ketua Lembaga Pengabdian Masyarakat pada IAIN Mataram. 
Panitia dan fasilitator yang ikut berpartisipasi dan berperan dalam kegiatan ini adalah pihak terkait seperti tokoh masyarakat, tokoh pemuda dan tim dari IAIN Mataram yang dilaksanakan pada tanggal 5-6 Agustus 2017. Koordinasi ini dilakukan dengan tujuan untuk mempersiapkan pelaksanaan kegiatan desa binaan dengan melibatkan seluruh komponen masyarakat sehingga kegiatan pengabdian dapat terlaksana dengan lancar dan sesuai dengan target yang diharapakan.

\section{Memberikan Pendidikan Dan Penyuluhan}

Kegiatan pendidikan dan penyuluhan dilaksanakan pada hari sabtuminggu tanggal 05-06 Agustus 2017 yang bertempat di masjid Al-Falah kelurahan Taman Sari Ampenan Kota Mataram dengan jumlah peserta sejumlah 30 orang (peserta diambil dari pengurus dan pengelola beberapa masjid yang ada di kelurahan Taman Sari Ampenan Kota Mataram, sedangkan narasumber terdiri dari 2 orang yaitu bapak Dr. KH. Zaidi Abdad yang merupakan tokoh agama, pimpinan pondok pesantren dan akademisi di Fakultas Syariah IAIN Mataram, narasumber berikutnya adalah bapak M. Sa'i, MA yang juga akademisi yaitu dosen fakultas Dakwah IAIN Mataram sekaligus menjadi kepala Lembaga Pengabdian Masyarakat pada IAIN Mataram, dan yang bertindak sebagai moderator yaitu Dr. H. Kadri, M.Si dan Dr. Jumarim, S.Ag.,M.Hi

\section{Tahap Tindak Lanjut dan Evaluasi}

Tahap tindak lanjut dari kegiatan ini dilakukan untuk menindak lanjuti kegiatan yang sudah dilaksanakan. Tahap evaluasi yang dilakukan yaitu berupa evaluasi proses dan hasil. Evaluasi proses dapat dilihat dari proses penyuluhan yang dilakukan dengan mengevaluasi respon peserta, penyampaian materi narasumber, terlaksananya kegiatan sesuai dengan jadual. Untuk evaluasi hasil, dilaksanakan evaluasi akhir dengan melihat aspek dari kegiatan yang sudah dilakukan. 
Tahap evaluasi yang dilakukan dengan melibatkan semua pihak yang terkait yang meliputi dosen pengabdi, pihak desa yang diwakili oleh ketua RT, Kepala Desa, Staf Desa, peserta kegiatan pengabdian masyarakat sehingga evaluasinya bersifat komprehensif.

\section{KESIMPULAN}

Adapun kesimpulan dari kegiatan ini adalah; (1) Kegiatan pengabdian dapat terlaksana dengan lancar yang tercermin dari maksimalnya peran dari setiap tim pelaksana kegiatan pengabdian. (2) Berubahnya pola pikir masyarakat terhadap pentingnya kapasitas dan peran masjid sebagai pusat pemberdayaan masyarakat. (3) Meningkatnya pemahaman masyarakat tentang kapasitas dan peran masjid. (4) Meningkatnya pemahaman masyarakat terkait dengan konsep peran dan pemberdayaan masyarakat melalui masjid. (5) Tersampaikannya informasi terkait kapasitas peran masjid sebagai pusat pemberdayaan. (6) Meningkatnya pemahaman masyarakat untuk lebih mencintai dan melestarikan kapasitas peran masjid dalam memberdayakan masyarakat.(7) Dapat meningkatkan aspek kesadaran dan pemahaman terkait dengan pentingnya peran masjid dalam memberdayakan umat/masyarakat

\section{DAFTAR PUSTAKA}

'Ajjaj al-Khatib, Muhammad, Ushul al-Hadist, Bierut: Dar al-Fikr, 1982.

Abdul Ghoffar, M, dkk, Terjemahan Ibnu Katsir, Bogor: Pustaka Imam Asy- Syafi'i, 2004.

Abubakar, Manajemen Berbasis IT, Yogyakarta : PT. Arina, 2007.

Agung, Masjid, Visi Misi dan Anggaran Dasar/Anggaran Rumah Tangga, Medan, 11 Juni 2016.

Aminudin, Hilmi, Menghilangkan Trauma Persepsi, Jakarta: Arah Press,2008

Anfanni Fahmi, Rizqi, Dari Masjid Membangun Umat ala Masjid Jogokariyan, Yogyakarta: Uiniversitas Islam Indonesia, 2015 
Transformasi, Vol. 13, No. 1, Januari 2017: 14 - 26

Annisa Zahro Munthe, Nurul, Hasil Wawancara, (Medan: Ahlusunnah WalJama'ah, 2016)

Asmid Nasution, M, Hasil Wawancara, Medan: Masjid Al-Ikhlas, 2016

Astari, Puji, Mengembalikan Fungsi Masjid sebagai Pusat Peradaban Masyarakat, IAIN Raden Intan Lampung :Jurnal Ilmu Da'wah dan Pengembangan Komunitas, 2014

Auliyah, Robiatul, Studi Fenomenolgi peranan manajemen masjid at-Taqwa dalam pemberdayaan ekonomi masyarakat Bangkalan, Madura:Universitas Trinujoyo Madura

Ayub, Mohammad, Manajemen Masjid, Jakarta: Gema Insani, 1996

Fauzi Bin Abdurrahman, Muhd, dkk, Performance Measurement Model of Mosques I, Malaisya: Jurnal Internasional, 2015

Gazalba, Sidi, Masjid Pusat Ibadat dan Kebudayaan Islam, Jakarta : Pustaka Antara, 1971

Hamid Syarif, Abd, Peranan Masjid dalam pengembangan ekonomi Islam: Sebuah kebijakan ekonomi Zaman Rasulullah

Husein Haikal, Muhammad, Sejarah Hidup Muhammad, Jakarta: PT. Mitra Kerjaya Indonesia, 2001

Jauhar Muchtar, Heri, Fikih Pendidikan Islam, Bandung: PT. Remaja Rosdakarya, 2005 